\title{
THE KAMAFUGITE-CARBONATITE ASSOCIATION IN THE ALTO PARANAÍBA IGNEOUS PROVINCE (APIP) SOUTHEASTERN BRAZIL
}

\author{
JOSE AFFONSO BROD ${ }^{1}$, SALLY A. GIBSON ${ }^{2}$, ROBERT N. THOMPSON ${ }^{3}$, TEREZA CRISTINA JUNQUEIRA-BROD ${ }^{1}$, \\ HILDOR JOSE SEER ${ }^{4}$, LÚ CIA CASTANHEIRA DE MORAES ${ }^{4}$ AND GERALDO RESENDE BOAVENTURA ${ }^{1}$
}

\begin{abstract}
The Late-Cretaceous Alto Paranaíba Igneous Province (APIP) comprises a variety of ultrapotassic rock-types, including kimberlites, lamproites and large volumes of kamafugites, in addition to a number of carbonatite-bearing plutonic alkaline complexes. Phlogopite-picrites are ultramafic fine-grained rocks typically composed of olivine phenocrysts set in a groundmass of phlogopite, carbonate, perovskite, apatite and chromite. They occur as dyke swarms in the carbonatite complexes, but are also scattered throughout the Province. The phlogopite-picrites represent the peralkaline, ultrapotassic, carbonate-rich, silicate magmas parental to the carbonatite-bearing complexes, and have strong chemical affinity with kamafugites. Together with petrographic similarities observed between silicate rocks from the carbonatite complexes and xenoliths occurring in APIP kamafugites, this provides a strong link between kamafugitic and carbonatitic magmatism in the Province.
\end{abstract}

Keywords: kamafugite, carbonatite, phlogopite.-picrite, ultrapotassic, APIP

INTRODUCTION AND GEOLOGICAL SETTING Voluminous magmatism occurred in central and southern Brazil, from Early Cretaceous until Eocene times. This includes the extensive EarlyCretaceous Parana continental flood basalt (CFB) province and a number of Early-Cretaceous to Eocene Alkaline Igneous Provinces that surround the Parana Basin. All of this magmatism has been associated with the thermal and/or chemical influence of mantleplumes (Tristan and Trindade) impacting on the base of the continental lithosphere (e.g. Herz 1977, Toyoda et al. 1994, Gibson et al. 1995a,b, 1997, VanDecar et al. 1995; Thompson et al 1998).

The products of the intense Late-Cretaceous alkaline magmatism at the northeastern border of the Parana Basin (Fig.l), in south-east Brazil, are collectively known as the Alto Paranaíba Igneous Province (APIP, Gibson et al. 1995b). The magma types include kimberlites, madupitic olivine lamproites and kamafugites, in addition to large intrusive carbonatite-bearing alkaline complexes. Rocks of kamafugitic affiliation are by far the most abundant in the APIP. Madupitic olivine lamproites are restricted to the NW portion of the province and diamondiferous (Gonzaga and Tompkins 1991) kimberlites, containing xenoliths of garnet Iherzolite (Leonardos et al. 1993, Carvalho and Leonardos 1995) occur at Tres Ranches (Goias State), in the north of APIP.

ALTO PARANAÍBA IGNEOUS PROVINCE CARBONATITE COMPLEXES A number of relatively large (up to $65 \mathrm{~km}^{2}$ ), intrusive, carbonatite-bearing ultramafic complexes are found in the province. These occurrences comprise Catalão I and Catalão II in southern Goiás State, and Serra Negra, Salitre I, Salitre II, Araxa and Tapira in western Minas Gerais State (Fig. 1). The complexes are multi-stage intrusions emplaced into Late-Proterozoic metamorphic rocks of the Brasilia mobile belt, which are typically deformed into dome structures.

The silicate-rock association in the carbonatite complexes includes dunites, wehrlites, clinopyroxenites, bebedourites, phoscorites and syenites. Rare melilitolite (uncompahgrite) has been described from the Tapira Complex (Guimaraes et al. 1980, Brod 1999). A striking feature of the APIP carbonatite complexes is the absence of nephelinerich rocks, such as those of the ijolite series, which are commonly associated with many carbonatite complexes worldwide. Instead, a major primary silicate rock-type in the APIP carbonatite complexes is bebedourite, that varies from fine- to coarse-grained (locally pegmatitic) and is sometimes strongly foliated. It consists mainly of diopsidic pyroxene with variable amounts of phlogopite, perovskite, apatite, magnetite, melanite and sphene. Modal variations in the essential mineral phases can produce facies rich in olivine (dunites, wehrlites), perovskite, magnetite or apatite. The Serra do Salitre (Salitre Mountains), within the APIP, is the type area for this rock, as defined by Troger( 1928).

The petrographic and chemical characteristics of syenitic rocks associated with the APIP carbonatite complexes indicate an ultrapotassic affinity. In thin section, altered patches composed of a

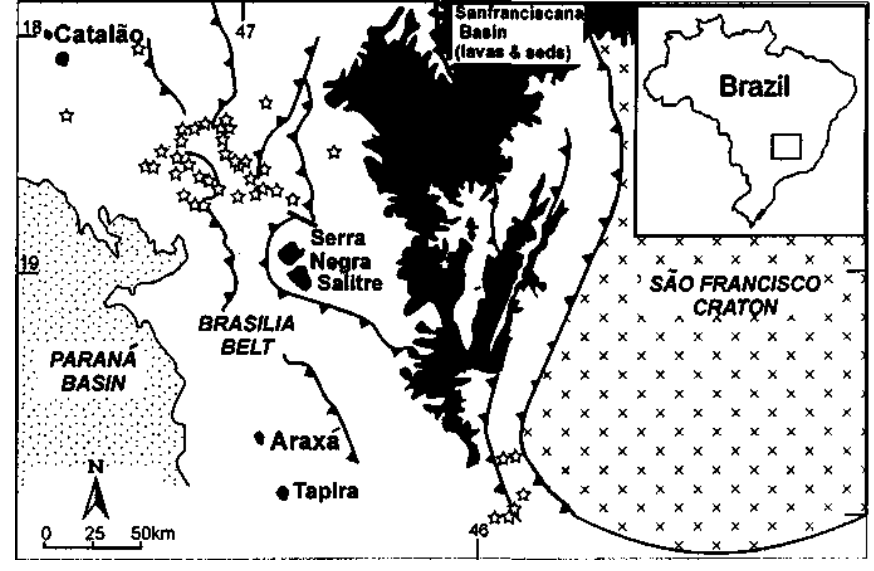

Figure 1-Location and geological setting of the Alto Paranaiba Igneous Province. The carbonatite-bearing complexes of Catalão, Serra Negra, Salitre, Araxá and Tapira are indicated individually. Smaller occurrences of APIP ultrapotassic rocks are shown by stars. The Sanfranciscana Basin includes both the Mata da Corda volcanics (not individualized) and the Areado sediments. Adapted from Gibson et al. (1995b).

mixture of carbonate, sericite and clay minerals often resemble the outlines of leucite crystals, whereas others resemble nepheline or kalsilite. An XRD reconaissance of Tapira syenites yielded a set of peaks consistent with the presence of leucite or analcinie. In samples from Salitre the XRD study indicated the presence of kalsilite (Brod 1999). These rocks are currently undergoing microprobe investigation.

Sovite and beforsite are dominant among the carbonatites, with subordinate silico-carbonatite (e.g. Catalão II, Machado Jr. 1992).

Ultramafic dykes are intimately associated with all APIP carbonatite complexes. The dykes are usually a few centimetres or tens of centimetres thick, rarely reaching more than one metre. These have been traditionally described as lamprophyres, on the basis of the abundant olivine and subordinate phlogopite phenocrysts. On other occasions they have been mistaken for metasomatic glimmerites, because of the high modal percentages of phlogopite and carbonate. Gibson et al. (1995b) and Brod (1999) demonstrated the magmatic character of these rocks. Flow differentiation, flow structures, porphyritic textures with euhedral phenocrysts, discordant tabular (dyke) shape of the intrusions, and carbonate ocelli are common primary magmatic features. Chilled margins are rare, but have been observed in dykes emplaced away from the carbonatite complexes.

Gibson et al. (1995b) stressed that such rocks do not fit the established nomenclature, and proposed the name phlogopite-picrite. No suitable alternative name appeared in the IUGS guidelines issued shortly after by Woolley et al. (1996) for the classification of alkaline potassic rocks. Therefore, the nomenclature proposed by Gibson et al.

1 Institute de Geociências-Universidade de Brasilia; CEP 70919-970, Brasilia-DF; Brazil, e-mail: brod@unb.br, tcjbrod@unb.br, grbunb@unb.br

2 University of Cambridge, Department of Earth Sciences, Downing Street, Cambridge. CB2 3EQ. UK; e-mail: sally@esc.cam.ac.uk

3 University of Durham, Department of Geological Sciences, South Road, Durham. DH1 3LE. UK; e-mail: r.n.thompson@durham.ac.uk

4 Curso Tecnico de Mineração, CEFET/MG; UNED/Araxá, Caixa Postal 208 - 38183070 - Araxá - MG, e-mail: seer.aax@terra.com.br 
(1995b) is adopted here; the name phlogopite-picrite is used for dykerocks essentially composed of phenocrysts of olivine and subordinate phlogopite, set in a groundmass of phlogopite, chromite, magnetite, perovskite, apatite and carbonate. The $\mathrm{MgO}$ contents of many samples certainly fit the latest IUGS definition of picrite (Le Bas, 2000). Although phlogopite-picrite dykes are typically associated with the carbonatite complexes, they are also found scattered throughout the province, with no obvious spatial relationship to carbonatites. Besides the obvious potassic character of their mineralogical assemblage, phlogopite-picrites also have textural similarities to other types of ultrapotassic rocks. Olivine phenocrysts may be coated by aggregates of equant small crystals of perovskite and oxides (chromite). This feature is similar to that described from kimberlites (e.g. Reid et al. 1975, Dawson and Hawthorne 1973), or by subhedral laths of phlogopite, similarly to olivine from lamproites (Mitchell and Bergman 1991). Mantling of olivine by phlogopite laths has also been reported by Gibson et al. (1994) from the Serra do Bueno kamafugitic diatreme, in the APIP. Phlogopite phenocrysts may be zoned towards tetra-ferriphlogopite, in samples where carbonate is modally abundant in the groundmass, a feature also observed in orangeites(Mitchell 1995). Carbonate-rich zones in the groundmass of phlogopite-picrite dykes may locally evolve to carbonate "pockets" of irregular or globular shape, suggesting that immiscibility of carbonate-rich liquid from the phlogopite-picrite magma may have occurred as early as during the formation of olivine. Carbonate immiscibility from unevolved silicate liquids has been documented from kimberlites and ultramafic lamprophyres (e.g. Dawson and Hawthorne, 1973; Pearce and Leng, 1996).

LINKS WITH ALTO PARANAÍBA IGNEOUS PROVINCE KAMAFUGITES The chemical and mineralogical affiliation of the Mata da Corda volcanic and pyroclastic rocks with the kamafugite series are now firmly established (Seer and Moraes 1988, Seer et al. 1989, Sgarbi and Valença 1993, 1994, Sgarbi and Caspar 1995, Gibson et al. 1995a). In addition, Gibson et al. (1995b) demonstrated the kamafugitic affinity of most of the alkaline silicate-rock intrusions in the remainder of the APIP.

Kamafugite lavas and tuff horizons of the Mata da Corda often contain xenoliths of plutonic rocks such as dunite, pyroxenite, melilitite and syenite. This rock association is also common in the carbonatite complexes of APIP. Seer and Moraes (1988) suggested that large amounts of these xenoliths in the volcanic breccias may indicate the presence of intrusive carbonatite-bearing complexes at depth. This is consistent with geophysical evidence (Bosum 1973), where some of the dipole anomalies observed in aeromagnetometry maps coincide with the known intrusive alkaline bodies, whilst numerous others may represent unexposed intrusions.

The composition of clinopyroxenite xenoliths in the Mata da Corda kamafugites (calcic augite, phlogopite, perovskite, apatite, melanite, opaque minerals and occasionally Ba-rich feldspar) closely resembles that of the bebedourites. In addition, nearly all of the textural features observed in bebedourites (Brod 1999) are also present in the Mata da Corda xenoliths (Seer and Moraes 1988, Lloyd and Bailey 1991, Brod 1999). It would therefore seem entirely appropriate to classify these rocks as bebedourite. In this context, another crucial piece of evidence comes from the presence of kalsilite in some of the Mata da Corda xenoliths, recently reported by Sgarbi et al. (1998). So far, kalsilite has not been positively identified in connection with the carbonatite complexes, but XRD evidence (Brod 1999) suggests the presence of kalsilite, in addition to nepheline, in syenitic dykes from Salitre, and the recognition of this mineral in bebedourites within the carbonatite complexes may be just a matter of time. Finally, phlogopite-picrites dykes, which are abundant in APIP carbonatite complexes, are also found cutting the Mata da Corda volcanic rocks (Gibson et al. 1995b).

The combined field, petrographic and geophysical evidence presented above, together with the obvious spatial and temporal association, strongly suggest that the plutonic counterparts of the Mata da Corda kamafugites are bebedourites. These are analogous to those occurring in the carbonatite complexes and thus provide an important link between the carbonatites and the kamafugitic magmatism in APIP.

GEOCHEMISTRY The Late Cretaceous magmatism in the Alto Paranaíba Igneous Province (APIP) has been the subject of numerous recent chemical and isotopic studies, which have attempted to identify the geochemical characteristics of the underlying mantle regions (e.g.
Toyoda et al. 1994, Bizzi et al. 1995, Gibson et al. 1995b, McDonald et al. 1995, Carlson et al. 1996). With the exception of Toyoda et al. (1994), a general consensus seems to emerge from these studies that the vast majority of APIP parental melts originated from metasomatised sub-continental lithospheric mantle (SCLM). The predominance of rocks with mineralogical and/or geochemical kamafugitic affiliation in both plutonic and volcanic settings of APIP, is also now widely recognised (e.g. Sgarbi and Valença 1993, Sgarbi and Caspar 1995, Sgarbi et al. 1998, Gibson et al. 1994, 1995b, Tompkins et al. 1998, Araujo et al. 1998).

Brod (1999) demonstrated that the phlogopite-picrite dykes are primitive magmas and that all of the silicate and carbonate primary (magmatic) rocks in the Tapira complex may be derived from them, through a complex interplay of liquid immiscibility and fractional crystallisation processes. This is likely to be the case in the other APIP carbonatite complexes as well, given their strong petrographic similarity and the intimate association of phlogopite-picrite dykes with all of them. Phlogopite-picrites thus provide an excellent opportunity for investigation of the geochemical affiliation of the parental magmas of APIP carbonatite complexes.

Major-element oxides
the phlogopite-picrites (and also of some more-evolved ultramafic,syenitic and carbonatitic dykes) must take into account the abundanceof some elements that are usually regarded as traces in other igneousrocks. For instance, in some samples, $\mathrm{Ba}$ and $\mathrm{Sr}$ can reach percentagelevels and must be included in the major-element analyses, in order toachieve acceptable analytical totals. A second problem posed by theserocks is that Loss on Ignition (LOI) values are mostly related to the presence of groundmass carbonate and/or carbonate globules (ocelli).Since in most cases this is a magmatic feature of phlogopitepicrites(Brod 1999), the usual technique of recalculating the analyses on a"dry" basis would induce unrealistic interpretation of the data.Therefore, data for major-element oxides are reported here on a "wet"basis.

Phlogopite-picrites display progressive variation in many of the major-element oxides, and are probably best considered as representing several stages of a differentiating series. The following general features can be regarded as typical of the phlogopite-picrite series. All samples are extremely silica-undersaturated $\left(\mathrm{SiO}_{2}=24.30\right.$ - 33.40 wt. \%), carbonate-rich (CC- $=3.29$ - 21.9 wt. \%) and strongly potassic $\left(\mathrm{K}_{2} \mathrm{O}=2.68-5.87\right.$ wt. \%). They typically have high $\mathrm{CaO}$ (9.31 -19.41 wt. \%) and $\mathrm{TiO}_{2}(3.24$ - 5.37 wt. \%) contents and are low in $\mathrm{AL}_{2} \mathrm{O}_{3}\left(1.63-4.69\right.$ wt. \%)/The $\mathrm{K}_{2} \mathrm{O} / \mathrm{Na}_{2} \mathrm{O}$ ratio varies from 2.14 to 14.86 , on a wt. \% basis. The high $\mathrm{MgO}$ (ff.73 - 21.34 wt. \%) testifies to the primitive character of these rocks. Their mg-number varies from 42 to 62 , and correlates positively with strongly compatible trace elements, such as $\mathrm{Cr}$ and $\mathrm{Ni}$.

Trace elements The high $\mathrm{Cr}$ (134 - 1012 ppm) and Ni (82-932 ppm) contents are consistent with the ultramafic character of these rocks and suggest that the least evolved members of the phlogopitepicrite series can be considered as primitive magmas. Scandium is moderately high, varying from 22 to $37 \mathrm{ppm}$. Phlogopite-picrites are strongly enriched in incompatible elements. In particular, $\mathrm{Ba}, \mathrm{Sr}$ and the sum of the rare-earth elements (REE) often reach concentrations of a few tenths of a percent. Concentrations of the high-field-strength elements (HFSE) are relatively high: $\mathrm{Nb}(160$ - 360 ppm); Ta (10 - 22 ppm); $\mathrm{Zr}$ (470 - $1000 \mathrm{ppm})$ and $\mathrm{Hf}(10-23 \mathrm{ppm})$. The trace-element distribution is illustrated in the chondrite-normalised spider diagram of Fig. 2.

It should be noted that all samples behave coherently in Fig. 2 Each pattern peaks at La, with the most enriched samples showing $\mathrm{La}$ concentration over 1600 times the chondritic abundance. Negative anomalies at $\mathrm{Rb}, \mathrm{K}$ and $\mathrm{Sr}$, together with a less pronounced negative $\mathrm{Ti}$ anomaly, are also present. Few samples show an incipient phosphorus negative anomaly. The chondrite normalised ratios of the "paired" elements, such as $\mathrm{Zr} / \mathrm{Hf}$, Y/Ho and $\mathrm{Nb} / \mathrm{Ta}$ show little variation, in the ranges 1.16-1.52, 8.6-9.9 and 0.58-1.34, respectively.

The REE patterns of the phlogopite-picrites are shown in Fig. 3. The patterns are smooth and steep, showing strong enrichment of the light rare-earth elements (LREE) relative to the heavy rare-earth elements (HREE). Chondrite-normalised $\mathrm{La} / \mathrm{Lu}$ ratios range from 69 to 210, but most are concentrated between 90 and 160. $\mathrm{La} / \mathrm{Sm}(\mathrm{N})$ ratios vary from 16.7 to 19.3 . 


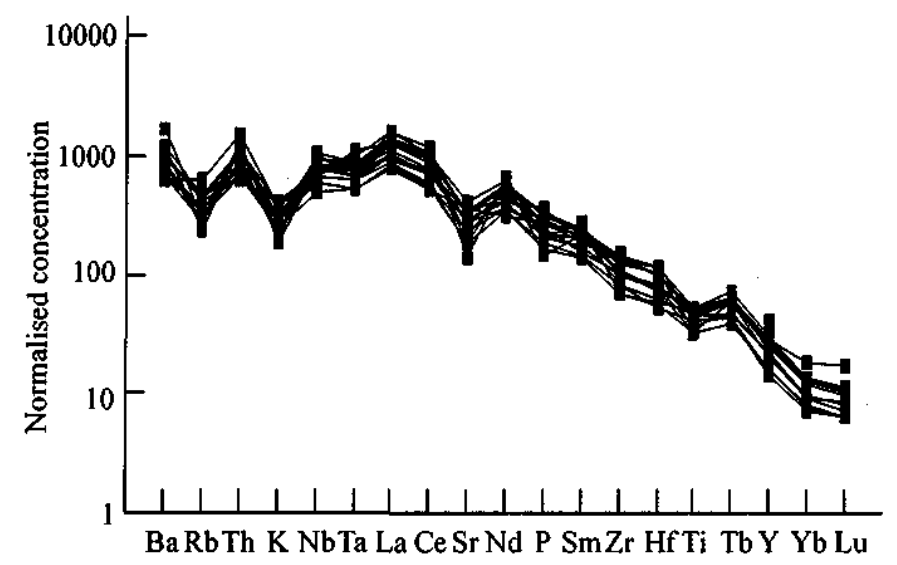

Figure 2-Trace-element diagram showing the composition of phlogopitepicrites, normalised to chondrite (except $R b, K$ and $P$ ) according to Thompson et al. $(1984)$.

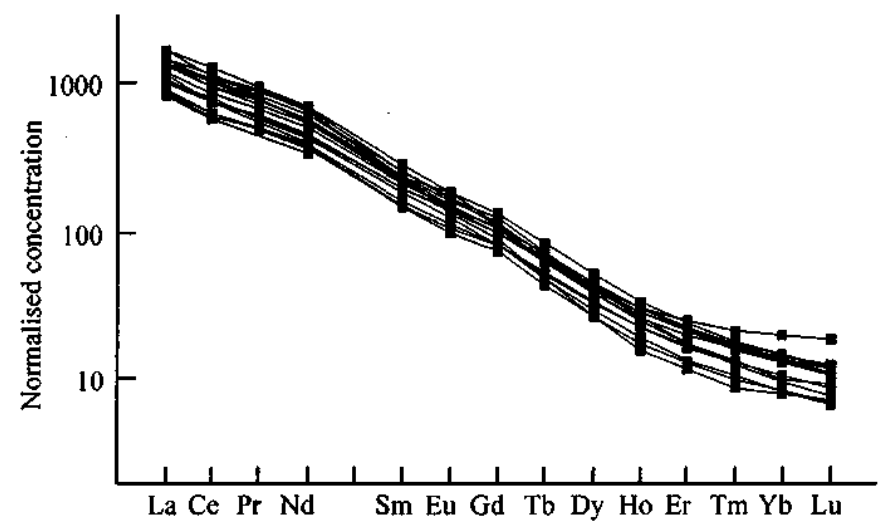

Figure 3-Chondrite-normalised REE patterns of phlogopite-picrites. Normalisation factors are from Boynton (1984).
Chemical classification of the phlogopite-picrites Any

attempt at a chemical classification of the phlogopite-picrites has to account for the peralkaline (mol. ratio of alkalis to aluminium from 1.04 to 3.02$)$ and ultrapotassic $\left(\mathrm{K}_{2} \mathrm{O} / \mathrm{Na}_{2} \mathrm{O}\right.$ from 2 to 15$)$ character of these rocks, as well as their extreme silica-undersaturation. Classification diagrams involving the relative abundance of silica and alkalis, such as those of Cox et al. (1979) and Le Maitre et al. (1989) are difficult to apply, because of the excessively low silica content of the phlogopite-picrites. Mitchell (1996) emphasised that the total alkalis vs. silica (TAS) diagram is "totally inadequate" for the classification of several types of alkaline rocks, such as kimberlites, lamproites, kamafugites, melilitites and nephelinites.

A chemical scheme for the classification of ultrapotassic rocks was devised by Foley et al. (1987). Before the system is applied, the wholerock analyses must pass a chemical screen $\left(\mathrm{MgO}>3\right.$ wt. \%, $\mathrm{K}_{2} \mathrm{O}>3$ wt. $\%$, and $\mathrm{K}_{2} \mathrm{O} / \mathrm{Na}_{2} \mathrm{O}>2$ ), in order to confirm the ultrapotassic character of the rock and to concentrate the classification on mafic varieties only. All the studied samples of phlogopite-picrite have $\mathrm{MgO}$ higher than 8 wt. \%, and only one fails to satisfy the minimum $\mathrm{K}_{2} \mathrm{O}$ limit, despite its relatively high $\mathrm{K}_{2} \mathrm{O} / \mathrm{Na}_{2} \mathrm{O}$ ratio. This sample shows textural evidence of alteration, which could be responsible for changes in the original $\mathrm{K}_{2} \mathrm{O}$ content.

Fig. 4 shows plots of phlogopite-picrite analyses from the Tapira complex in a number of the classification diagrams proposed by Foley et al. (1987). The phlogopite-picrites invariably plot within or near the field of Group II ultrapotassic rocks (kamafugites). Although the mineralogy of these rocks does not warrant their classification as kamafugites in a petrographic sense, their geochemical affinity with the kamafugitic series is obvious, at least in terms of major elements. Data from Gibson et al. (1995b) for kamafugitic rocks of the APIP and for phlogopite-picrites associated with other carbonatite complexes in the province are also plotted in Fig. 4, for comparison. Phlogopite-picrites from Tapira have slightly lower $\mathrm{SiO}_{2}$ and $\mathrm{Al}_{2} \mathrm{O}_{3}$ than the APIP kamafugites and higher $\mathrm{CaO}$ than phlogopite-picntes from other APIP carbonatite complexes. The $\mathrm{K}_{2} \mathrm{O} / \mathrm{AL}_{2} \mathrm{O}_{3}$, ratio is higher in Tapira phlogopite-picrites than in both groups of APIP rocks.

The geochemical affinity of phlogopite-picrites with kamafugitic rocks is also observed in trace-element ratio diagrams, such as $\mathrm{Th} / \mathrm{Yb}$ vs. $\mathrm{Ta} / \mathrm{Yb}$ and $\mathrm{Th} / \mathrm{Zr}$ vs. $\mathrm{Nb} / \mathrm{Zr}$ (Fig. 5). Both diagrams show that phlogopite-picrites and APIP kamafugites plot at the higher end of the array of rocks derived from non-subduction-related mantle sources.
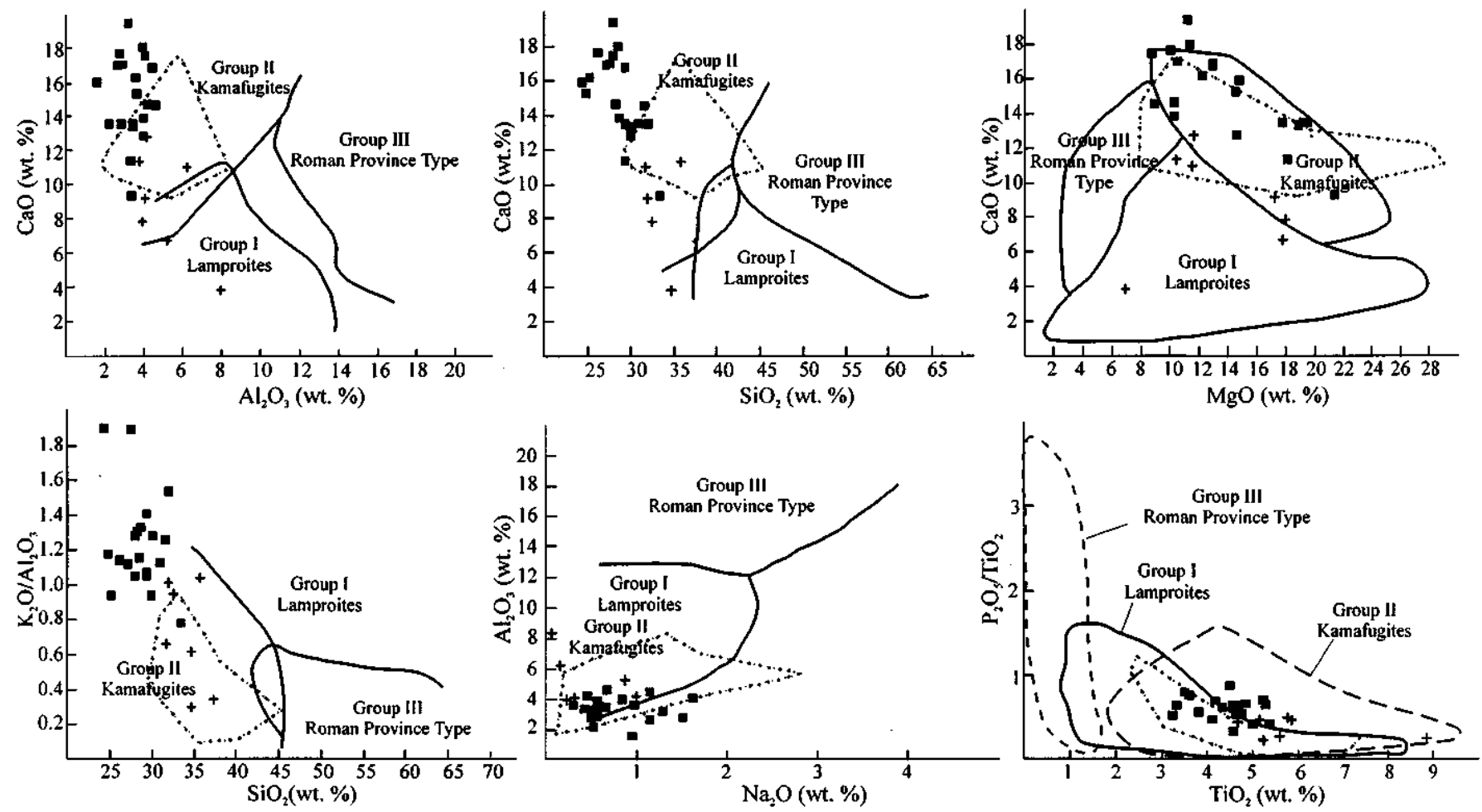

Figure 4-Major-element variation in the classification diagrams of Foley et al. (1987), showing the composition of Tapira phlogopite-picrites (squares). Data for other APIP phlogopite-picrites (crosses) and APIP kamafugites (fields outlined by dotted lines) are from Gibson et al. (1995b) and Brod (1999). 


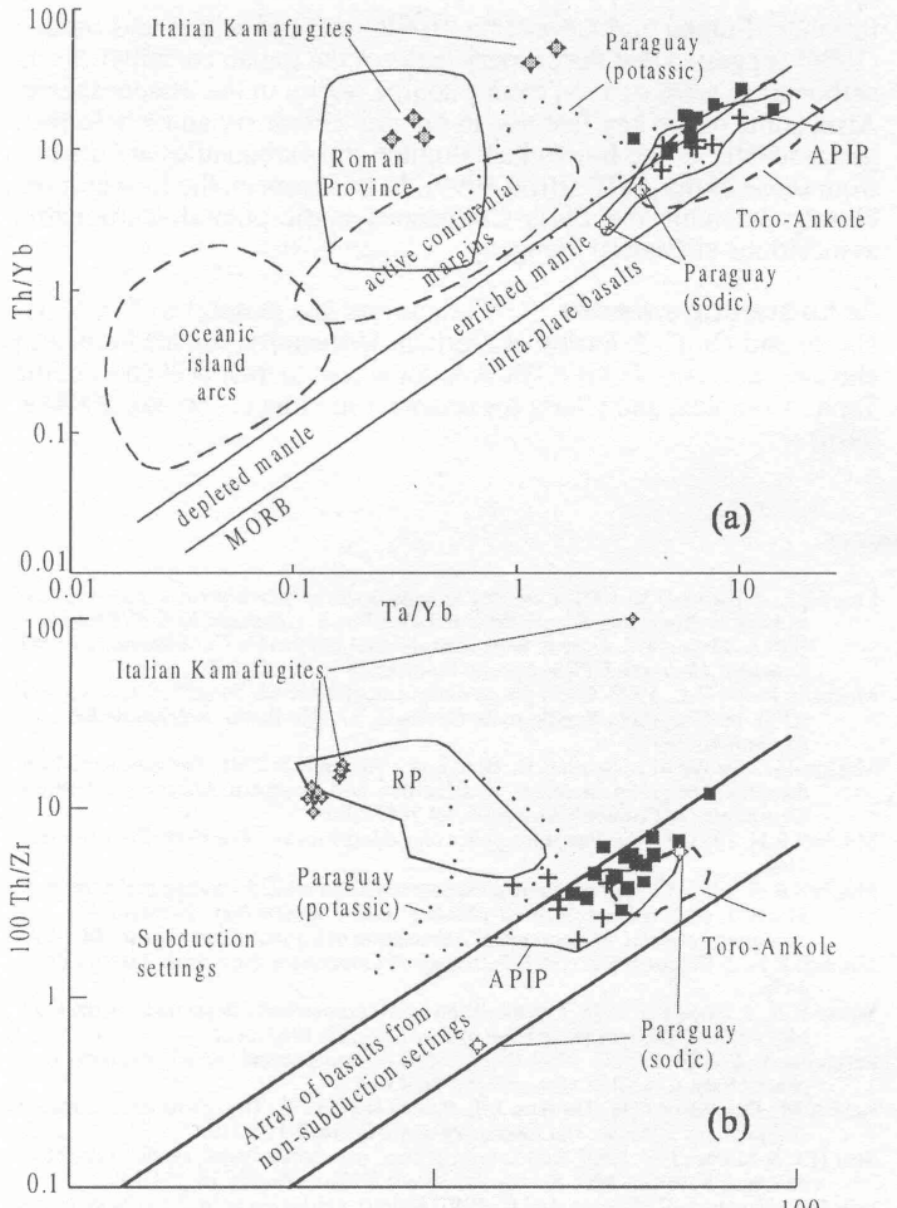

10

$100 \mathrm{Nb} / \mathrm{Z}$

Figure 5-A) Th/Yb vs. Ta/Yb diagram showing the composition of Tapira phlogopite-picrites (solid squares), compared with other rock types. Data for potassic and sodic rocks from Paraguay are from Comin-Chiaramonti et al. (1997), Italian kamafugites from Conticelli and Peccerillo (1992) and from Peccerillo et al. (1988), APIP rocks from Gibson et al. (1995b). Other fields are from Wilson (1989), and references therein. B) $\mathrm{Th} / \mathrm{Zr} v \mathrm{vs}$. Nb/Zr diagram, showing the composition of phlogopite-picrites from Tapira (solid squares) and other APIP phlogopite-picrites (crosses), compared with potassic rocks from other provinces. Data for APIP rocks are from Gibson et al. (1995b), Italian kamafugites are from Conticelli and Peccerillo (1992) and Peccerillo et al. (1988). Other fields are after Comin-Chiaramonti et al. (1997).

The chemical similarity of APIP rocks to the Toro-Ankole kamafugites is also evident. The APIP rocks are distinct from other potassic rocks, such as those from the Roman Province-type, Italian kamafugites and Eastern Paraguay, which have lower relative concentrations of $\mathrm{Nb}$ and Ta. Sodic alkaline igneous rocks from Paraguay, however, have compositions analogous to APIP, a feature also noted by CominChiaramonti et al. (1997), who assumed that their mantle source was similar to that postulated by Gibson et al. (1995b) for the Alto Paranaíba ultrapotassic magmas.

Fig. 6 compares the chondrite-normalised ratios of trace elements in the Tapira phlogopite-picrites with those of other examples of alkaline rocks. The pattern for Tapira samples agrees well with those of the APIP kamafugites and shows a nearly perfect coincidence with phlogopite-picrites from other carbonatite complexes in the province. Both the Ugandan and Italian examples of kamafugites are less enriched in most elements than the APIP rocks. Additionally, the Italian kamafugites exhibit characteristic negative anomalies at $\mathrm{Nb}$ and $\mathrm{Ta}$, which are lacking in the Ugandan and APIP rocks. The negative anomalies of $\mathrm{K}$ and $\mathrm{Rb}$ are more pronounced in the sample of APIP kimberlite than in the phlogopite-picrites. APIP lamproitic rocks are distinguished from the phlogopite-picrites by their lower contents of $\mathrm{LREE}$, and by the absence of negative $\mathrm{Rb}$ and $\mathrm{K}$ anomalies.
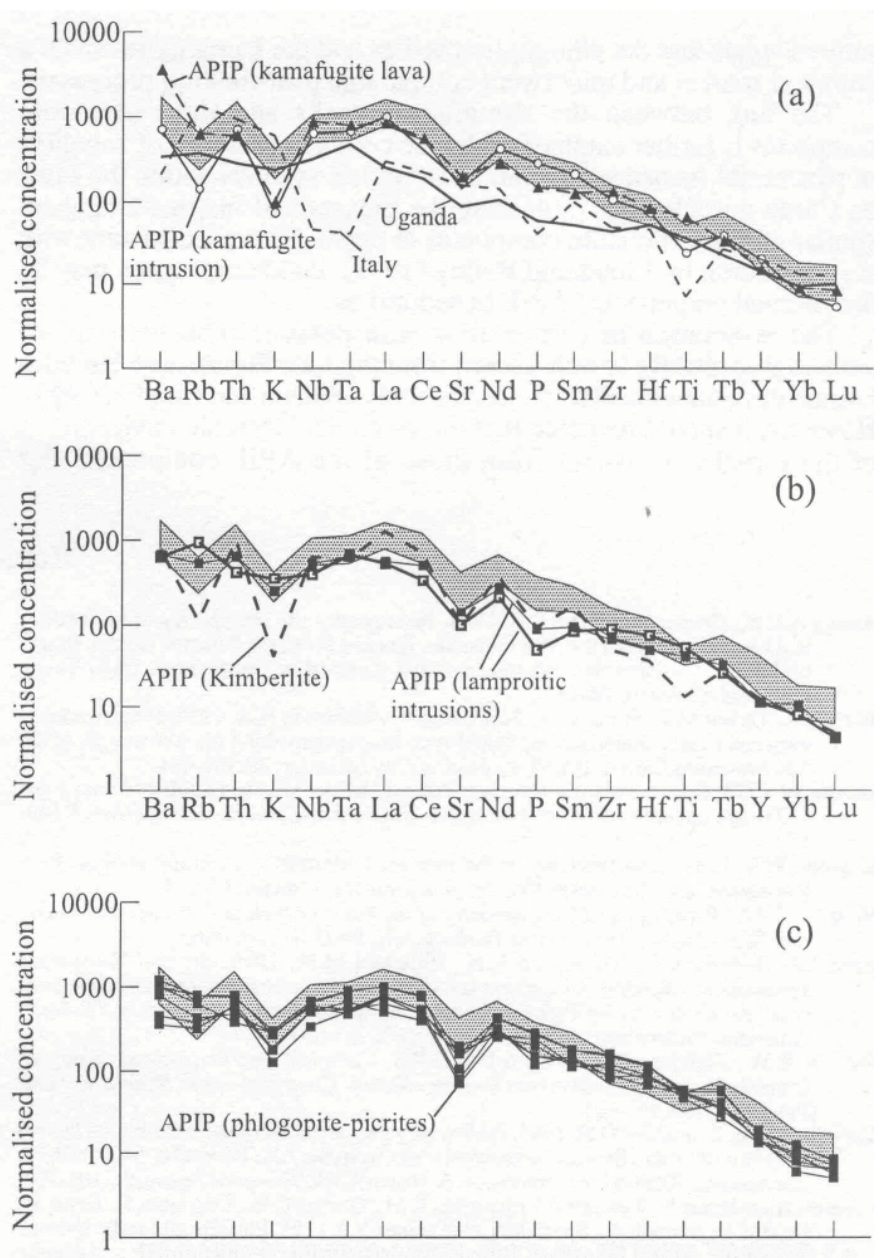

BaRbTh K NbTa La Ce Sr Nd P SmZr HfTi TbY Yb Lu

Figure 6-Spider diagrams comparing the composition of Tapira phlogopitepicrites (shaded field) with: (a) kamafugites from APIP (Gibson et al. 1995b), Italy (Peccerillo et al. 1988) and Uganda (Thompson et al. 1984); (b) kimberlite and lamproitic rocks from APIP (Gibson et al 1995b); (c) phlogopite-picrites associated with other APIP complexes (Gibson et al. 1995b). Concentrations normalised to chondrite (except Rb, $K$ and $P$ ) according to Thompson et al. (1984).

Finally, initial ${ }^{87} \mathrm{Sr}{ }^{86} \mathrm{Sr}$ and ${ }^{143} \mathrm{Nd} /{ }^{14} \mathrm{Nd}$ ratios obtained by Brod et al (1999) for carbonatites and silicate rocks of the Tapira complex are within the overall range of the APIP rocks (Gibson et al. 1995b) suggesting a broadly similar mantle source region for the carbonatite and ultrapotassic magmatism.

DISCUSSION AND CONCLUSIONS Detailed variations in the chemical properties of kamafugites, lamproites and kimberlites from APIP led Gibson et al. (1995b) to suggest heterogeneities in the melt source regions of these rocks. Thus, they interpreted the high $\mathrm{CaO}$ and Sc of the kamafugites as indicative of a clinopyroxene-rich mantle source. The favoured mechanism for the production of the postulated source mineralogy is the conversion of mantle harzburgite or Iherzolite to wehrlite by reaction with dolomitic carbonatite melt (e.g. Dalton and Wood 1993, Moore and Wood 1998), which is believed to take place at relatively low pressures $(<25$ kbars $)$. On the other hand, highpressure assemblages in xenoliths (Carvalho and Leonardos 1995) from the Tres Ranches kimberlite suggest a much deeper $(>150 \mathrm{~km})$, clinopyroxene-depleted source for this kimberlite. The mantle source of APIP lamproites is interpreted as somewhat depleted in clinopyroxene with respect to the kamafugites (Gibson et al. 1995b). The evidence presented in this paper strongly suggests that the origin of the APIP carbonatites is inextricably linked with the ultrapotassic magmatism. The bulk-rock chemistry in the phlogopitepicrites from Tapira and other carbonatite complexes most closely resemble the chemical features of the APIP kamafugites (e.g. Mata da Corda volcanics). In particular, similarities in trace-element and REE 
ratios suggest that the phlogopite-picrites and the kamafugites share a common source, and underwent comparable post-melting processes.

The link between the kamafugitic rocks and the carbonatite complexes is further emphasised by the common presence of xenoliths da Corda pyroclastics, indicating the presence of magma chambers similar to the carbonatite complexes at depth. This is consistent with the suggestion by Lloyd and Bailey (1991), that kamafugites may be the parental magmas for APIP bebedourites.

The association of carbonatites with potassic igneous rocks of kamafugitic affinity is well known from the Late Pleistocene UmbriaLatium ultra-alkaline district, Central Italy (Stoppa and Cundari 1995). However, it should be noted that the origin and tectonic environment of these rocks is distinct from those of the APIP complexes. For of pyroxenite (bebedourite) and ultrapotassic syenites within the Mata

instance, Stoppa and Lavecchia (1992) and Lavecchia and Stoppa (1996) suggested that the primary melts of the Italian kamafugites and carbonatites were derived from a source region in the asthenosphere. Also, some of the key features in mineral chemistry and whole-rock geochemistry of the Italian kamafugites and carbonatites are distinct from those of the APIP (Brod 1999). In this respect, the former more closely resemble the Early-Cretaceous mafic-potassic/carbonatite associations of Eastern Paraguay.

Acknowledgements The authors are grateful to Mr. R. G. Hardy and Dr. C. J. Ottley at Durham University, for the help with chemical analyses, FOSERTIL S.A. for access to their drill cores of the Tapira Complex, and CNPq for financial funding (Grant no. 200449/ 94-0)

\section{References}

Araujo A.L.N., Caspar J.C., Bizzi L.C. 1998. Petrography and mineralogy of kimberlites and kamafugites from the Alto Paranaíba Igneous Province, Mineras Gerais, Brazil preliminary studies. In: 7th International Kimberlite Conference, Cape Town, Extended Abstracts, 26-28.

Bizzi L.A., DeWit M.J., Smith C.B., McDonald I., Armstrong R.A. 1995. Heterogeneous enriched mantle materials and Dupal-type magmatism along the SW margin of the São Francisco Craton, Brazil. Journal of Geodynamics, 20:469-491.

Bosum W. 1973. O levantamento aeromagnetico de Minas Gerais e Espirito Santo e sua sequência quanto a estrutura geologica. Revista Brasileira de Geociências, 3:149159 .

Boynton W.V. 1984. Geochemistry of the rare earth elements: meteorite studies. In P. Henderson, ed., Rare earth element geochemistry, Elsevier, 63-114.

Brod J.A. 1999. Petrology and Geochemistry of the Tapira Alkaline Complex, Minas Gerais State, Brazil. University of Durham, UK, Ph.D. Thesis, 486

Brod J.A., Gibson S.A., Thompson R.N., Pimentel M.M. 1999. Sr- and Nd-isotope systematics: The relationships between silicate rocks and carbonatites and the role of crust assimilation in the Tapira carbonatite complex, Minas Gerais, Brazil. In: South American Symposium on Isotope Geology, 2, Adas, 170-173

Carlson R.W., Esperanca S., Svisero D.P. 1996. Chemical and Os isotopic study of Cretaceous potassic rocks from Southern Brazil. Contributions to Mineralogy and Petrology, 125:393-405.

Carvalho J.B. \& Leonardos O.H. 1995. Preliminary geothermobarometric studies on mantle xenoliths of kimberlites and associated rocks from the Alto Paranaíba, SE Brazil. In: International Kimberlite Conference, 6, Novosibirsk, Extended Abstracts, 101-103.

Comin-Chiaramonti P., Cundari A., Piccirillo E.M., Gomes C.B., Castorina E, Censi P., DeMin A., Marzoli A., Speziale S., Velazquez V.E 1997. Potassic and sodic igneous rocks from eastern Paraguay: Their origin from the lithospheric mantle and genetic relationships with the associated Parana flood tholeiites. Journal of Petrology, 38:495-528

Conticelli S. \& Peccerillo A. 1992. Petrology and geochemistry of potassic and ultrapotassic volcanism in central Italy - petrogenesis and inferences on the evolution of the mantle sources. Lithos, 28:221-240.

Cox K.G., Bell J.D., Pankhurst R.J. 1979. The interpretation of igneous rocks. London,

Alien, Unwin. 450pp.
Dalton J.A. \& Wood B.J. 1993. The compositions of primary carbonate melts and their evolution through wallrock reaction in the mantle. Earth and Planetarv Science Letters, 119:511-525.

Dawson J.B. \& Hawthorne J.B. 1973. Magmatic sedimentation and carbonatitic differentiation in kimberlite sills at Benfontein, South Africa. Journal of the Geological Society of London, 129:61-85.

Foley S.F., Venturelli G., Green D.H., Toscani L. 1987. The ultrapotassic rocks characteristics, classification, and constraints for petrogenetic models. Earth-Science Reviews, 24:81-134.

Gibson S.A., Thompson R.N., Leonardos O.K., Turner S.E., Mitchell J G., Dickin, A.P. 1994. The Serra do Bueno potassic diatreme - a possible hypabyssal equivalent of the ultramafic alkaline volcanics in the late Cretaceous Alto Paranaíba Igneous Province, SE Brazil. Mineralogical Magazine, 58:357-373.

Gibson S.A., Thompson R.N., Dickin A.P., Leonardos O.H. 1995a. High-Ti and low-Ti mafic potassic magmas: Key to plume-lithosphere interactions and continental floodmafic potassic magmas: Key to plume-lithosphere interactions and

Gibson S.A., Thompson R.N., Leonardos O.K., Dickin A.P., Mitchell J.G. 1995b. The Late Cretaceous impact of the Trindade mantle plume - evidence from large-volume, mafic, potassic magmatism in SE Brazil. Journal of Petrology, 36:189-229.

Gibson S.A., Thompson R.N., Dickin A.P., Mitchell J.G. 1997. Temporal variation in magma sources related to the impact of the Tristan mantle plume. In: C.J. Hatton, ed, PPM'97 International Symposium on plumes, plates \& mineralisation, Pretoria, Abstracts, 37-38.

Gonzaga G.M. \& Tompkins L.A. 1991. Geologia do diamante. In: Principais depositos minerals dv Brasil. Vol. 4a. Brasilia, DNPM/CPRM, 42-58.

Guimaraes I.G., Amaral M.A.M., Garcia L.R.A. 1980. Uncompahgrito de Tapira, MG. In: Congresso Brasileiro de Geologia, 31, Balneario de Camboriu, Anais 4:2050-2058.

Herz N. 1977. Timing of spreading in the South Atlantic: information from Brazilian alkalic rocks. Geological Society of America Bulletin, 88:101-112

Lavecchia G. \& Stoppa F.(1996. The tectonic significance of Italian magmatism - an alternative view to the popular interpretation. Terra Nova, 8:435-446.

Le Bas M.J. 2000. IUGS reclassification of the high-Mg and picritic volcanic rocks. Journal of Petrology in press.

Le Maitre R.W., Bateman P., Dudek A., Keller J., Lameyre J., Le Bas M.J., Sabine P.A Schmid R., Sorensen H., Streckeisen A., Woolley A.R., Zanettin B. 1989. A classification of Igneous rocks and glossary of terms: recommendations of the International Union of Geological Sciences Subcommission on the Systematics of Igneous Rocks. Oxford, Blackwell, 193p.

Leonardos O.H., Carvalho J.B., Tallarico F.H.B., Gibson S.A., Thompson R.N., Meyer H.O.A., Dickin A.P. 1993. O xenolito de granada Iherzolito de Tres Ranches 4: uma rocha matriz do diamante na provfncia magmatica cretacea do Alto Paranaíba. In: Simpósio de Geologia do Diamante, 1, Cuiaba, Anais, Universidade Federal do Mato Grosso, Special Publication 2/93. 3-16.
Lloyd RE. \& Bailey D.K. 1991. Complex mineral textures in bebedourite: possible links with alkali clinopyroxenite xenoliths and kamafugitic volcanism. In: O.H. Leonardos, H.O.A. Meyer, J.C. Caspar, eds., International Kimberlite Conference, 5, Araxá, Extended Abstracts, CPRM Special Publication 3/91.263-269.

Machado Junior D.L. 1992. Geologia do complexo alcalino-carbonatitico de Catalão II (GO). In: Congresso Brasileiro de Geologia, 37, São Paulo, Boletim de Resumos Expandidos, 94-95.

McDonald I., De Wit M.J., Smith C.B., Bizzi L.A., Viljoen K.S. 1995. The geochemistry of the platinum-group elements in Brazilian and Southern African kimberlites.

Mitchell R.H. 1995. Kimberlites, orangeites and related rocks. New York, Plenum Press. $41 \mathrm{Op}$.

Mitchell R.H. 1996. Classification of undersaturated and related alkaline rocks. In: R.H. Mitchell, ed., Undersaturated alkaline rocks: mineralogy, petrogenesis, and economic potential, Mineralogical Association of Canada Short Course, 24:1-22.

Mitchell R.H. \& Bergman S.C. 1991. Petrology of Lamproites. New York, Plenum Press. $447 \mathrm{p}$.

Moore K.R. \& Wood B.J. 1998. The transition from carbonate to silicate melts in the CaOMgO-SiO2-CO2 system. Journal of Petrology, 39:1943-1952.

Peccerillo A., Poli G., Serri G. 1988. Petrogenesis of orenditic and kamafugitic rocks from central Italy. Canadian Mineralogist, 26:45-65. "kimberlites". Physics and Chemistry of the Earth, 9:199-219.

Seer H.J. \& Moraes L.C. 1988. Estudo petrograiico das rochas igneas alcalinas da região de Lagoa Formosa, MG. Revista Brasileira de Geociências, 18:134-140.

Seer H.J., Moraes L.C., Fogaça A.C.C. 1989. Roteiro geologico para a região de Lagoa Formosa-Chumbo-Carmo do Paranaiba, MG. Belo Horizonte, SBG-MG. 58p.

Sgarbi P.B.A., Clayton R.N., MayedaT.K., Caspar J.C. 1998. Oxygen isotope thermometry of Brazilian potassic volcanic rocks of kamafugitic affinities. Chemical Geology, 146:115-126.

Sgarbi P.B.A. \& Caspar J.C. 1995. Perpvskites from the mata da corda kamafugites, MG, Brazil. In: International Kimberlite Conference, 6, Novosibirsk, Extended Abstracts, 498-499.

Sgarbi P.B.A. \& Valença J.G. 1994. Mineral and rock chemistry of the Mata da Corda kamafugitic rocks (MG State, Brazil). In: International Symposium on the Physics and Chemistry of the Upper Mantle, São Paulo, Extended Abstracts, 27-29.

Sgarbi P.B.A. \& Valenfa J.G. 1993. Kalsilite in Brazilian kamafugitic rocks. Mineralogical Magazine, 57:165-171.

Stoppa F. \& Cundari A. 1995. A new Italian carbonatite occurrence at Cupaello (Rieti) and its genetic significance. Contributions to Mineralogy and Petrology, 122:275-288.

Stoppa F. \& Lavecchia G. 1992. Late Pleistocene ultra-alkaline magmatic activity in the Umbria-Latium region (Italy) - an overview. Journal of'Volcanology and Geothermal Research, 52:277-293.

Thompson R.N., Gibson S.A., Mitchell J.G., Dickin A.P., Leonardos O.K., Brod J.A., Greenwood J.C. 1998. Migrating Cretaceous-Eocene magmatism in the Serra do Mar alkaline province, SE Brazil: Melts from the deflected Trindade mantle plume? Journal of Petrology, 39:1493-1526.

Thompson R.N., Morrison M.A., Hendry G.L., Parry S.J. 1984. An assessment of the relative roles of crust and mantle in magma genesis: an elemental approach. Phil. Trans. R. Soc. London, A310:549-590.

Tompkins L.A., Taylor W.R., Ramsay R.R., Armstrong R. 1998. The mineralogy and geochemistry of the kamafugitic Tres Barras Intrusion, Mata da Corda, Minas Gerais, Brazil. In: International Kimberlite Conference, 7, Cape Town, Extended Abstracts, 920-922

Toyoda K., Horiuchi H., Tokonami M. 1994. Dupal anomaly of Brazilian carbonatites geochemical correlations with hotspots in the South-Atlantic and implications for the mantle source. Earth and Planetary Science Letters, 126:315-331.

Tröger E. 1928. Alkaligesteine aus der Serra do Salitre im westlichen Minas Geraes, Brasilien. Centralblatt fur Mineralogie, Geologie und Palaontologie, Abt A:202204.

VanDecar J.C., James D.E., Assumpção M. 1995. Seismic evidence for a fossil mantle plume beneath South America and implications for plate driving forces. Nature 378:25-31.

Wilson M. 1989. Igneous Petrogenesis - A Global Tectonic Approach. London, Harper Collins. 466pp.

Woolley A.R., Bergman S.C., Edgar A.D., Le Bas M.J., Mitchell R.H., Rock N.M.S., Smith B.H.S. 1996. Classification of lamprophyres, lamproites, kimberlites, and the kalsilitic, melilitic, and leucitic rocks. Canadian Mineralogist, 34:175-186.

Contribution IGC-110

Received March 2, 2000 Accepted for publication May 5, 2000 Geochimica et Cosmochimica Acta, 59:2883-2903.

Reid A.M., Donaldson C.H., Dawson J.B., Brown R.W. 1975. The Igwisi Hills extrusive 